\title{
Learning Outcome of Students on Chemondro Media (Chemistry on Android) with Flipped Classroom Model on Electrolyte Solution
}

\author{
Dimas Ridho \\ Program of Postgraduate, \\ State University of Yogyakarta \\ Yogyakarta, Indonesia \\ email : dimasridho66@gmail.com
}

\author{
Jaslin Ikhsan \\ Program of Postgraduate, \\ State University of Yogyakarta \\ Yogyakarta, Indonesia
}

\begin{abstract}
This study aimed to determine the effect of chemondro media in flipped classroom model on student learning outcomes of grade X IPA students of SMAN on electrolyte solution. This research is a quasi-experimental research. The population of this research was all of students of grade $X$ SMAN in Gunung Kidul Regency. These samples included 102 students consisting of 51 students in the experimental class and 51 students in the control class. The multiple choice question was used as the data collection technique. This research used content validation and empirical validation. The result of validation showed the instruments were valid and reliable. The data were analyzed using Multivariate Analysis of Variance Test. The results of this research are as follows learning chemondro media in flipped classroom model significantly influenced the student learning outcome of grade $X$ students of SMAN on electrolyte solution.
\end{abstract}

Keywords - learning outcome, android, flipped classroom, electrolyte solution

\section{INTRODUCTION}

The development of information and communication technology has a great influence on patterns of relationships between individuals and others. The term information technology itself includes hardware, computer software, voice, data, networks and other communications technologies, including application and multimedia development tools. This technology is used as a means to acquire, process, store and disseminate information [9]. And the results by using technology media in learning will show good learning achievement and show interest in student learning to learn [4].

Make the learning media as a dominant learning source than educators [10]. With the purpose of effectiveness in learning writing also replace learning face to face with the interaction of learning based on information and communication technology. This is in accordance with the results of research conducted that interactive multimedia learning media capable of stimulating one or more human senses. With more and more senses involved in the learning process, the learning process will run more effectively.

The students' graduates' qualifications that students' graduate competency is the result of students' ability which is expected to be achieved after completing learning in the form of students' knowledge, attitude and skill [11]. However, based on an assessment survey shows Indonesian students do not meet good performance standards in science learning, including chemistry learning with average score of 403 which is still far from PISA standard (Program for International Student Assessment) is 496 average score [6]. And in the academic year 2016/2017 student learning outcomes in Gunung Kidul Regency are low with the National Exam results on chemistry subjects with an average of 54.73.

The low learning outcomes of students can be overcome by implementing chemistry learning by using learning methods that put students as learners. The recommended learning method is the learning method blended learning integrated flipped classroom model on learning media. The learning method of blended learning facilitates learning that incorporates classical teaching with virtual teaching [5]. This means that students are given a different atmosphere in finding concepts and principles during the learning process takes place. The impact of flipped classroom proves that with this model it gives more learning outcomes than classical learning [3]. The Flipped classroom model of learning, this model applies traditional learning that should be in class but applied at home. And if the traditional learning is done at home then complete the homework in the classroom during the lesson [2].

The success of a teacher in developing and utilizing the source of learning relies heavily on insights, teaching methods and planning in learning [7]. One of the learning resources that have been developed is the chemondro (chemistry on android) media on electrolyte solution materials to improve learning outcomes and independence of SMA / MA students developed [15]. Chemondro Media is an interactive learning medium on android users that includes the concept of chemical theory, in-game questions and virtual lab simulations.

Based on the problem, the need of learning model and strategy that can fulfill the demand of competency standard of curriculum graduates of 2013, both soft skill and hard skill, such as students' learning ability. Therefore, researchers conducted a study that aims to determine the effect of using 
the chemondro media on the model of learning flipped class on the ability of student learning outcomes in SMAN on the material of electrolyte solution.

\section{RESEARCH METHOD}

The type of research used in this study is quantitative research. Quantitative research is a study that uses quantitative data. Data in quantitative research is in the form of numbers or data that are used and uses statistical tests to analyze data. The type of research used in this study is quasi experimental research (quasi experimantal research). The experimental design of this research is posttest only control design.

In this design there are two groups: the control group and the experimental or treated group. Both groups were selected randomly, then treated the experimental group and gave no treatment to the contrast class. The scheme of posttest only control design is as follows Table 1:

TABLE 1. Posttest only control design.

\begin{tabular}{|c|c|c|}
\hline Group & Treatment & Posttest \\
\hline $\mathrm{E}^{\mathrm{a}}$ & $\mathrm{X}_{1}{ }^{\mathrm{c}}$ & $\mathrm{O}^{\mathrm{d}}$ \\
\hline $\mathrm{C}^{\mathrm{b}}$ & & $\mathrm{O}^{\mathrm{e}}$ \\
\hline \multicolumn{3}{|c|}{${ }^{\mathrm{a}}$ Experiment Group } \\
& ${ }^{\mathrm{b}}$ Control Group \\
& ${ }^{\mathrm{c}}$ Posttest Experiment Group \\
& ${ }^{\mathrm{d}}$ Posttest Control Group \\
& ${ }^{\mathrm{e}}$ Flipped classroom model
\end{tabular}

The research was conducted in SMA Negeri 2 Playen and SMA Negeri 1 Karangmojo Gunung Kidul Province Daerah Istimewa Yogyakarta. Both schools were chosen as research sites because the school has implemented the 2013 curriculum and has never applied the chemondro media to the flipped class model in electrolyte solution materials either as a selfreflection medium or as a step to develop student learning outcomes.

The study was conducted in December 2017 up to January 2018 in class $X$ of the academic year 2017/2018. This research involves several parties in taking data. Research personnel include researchers, namely students of Yogyakarta State University who conducted research as a lecturer at SMA Negeri 2 Playen and SMA Negeri 1 Karangmojo and who acted as a documentary during the learning process, is colleague of researchers who did the taking of documentation.

Population in this research is all student of class X IPA SMAN in Gunung Kidul Regency. The sample was taken by using purposive sampling technique with school criteria using $5 \mathrm{M}$ learning. The sample used is 2 classes obtained by drawing from 4 science classes in both schools. In SMA Negeri 1 Karangmojo, the class used is class X MIPA 1 as the experimental class with the number of students 29 students and class X MIPA 2 as the control class with the number of students 27 students. And in SMA Negeri 2 Playen, the class used is class X MIPA 2 as the experimental class with the number of students 22 students and class X MIPA 3 as the control class with the number of students 24 students.

This study consists of 3 stages, namely the preparation, implementation and retrieval of data. The preparation stage involves conducting preliminary observations at SMA Negeri 2 Banguntapan for 1 week by observing the chemistry learning activities in class X IPA and conducting interviews to chemistry teachers and XA IPA students about the learning activities that have been applied. Then select the nonrandom sample study class with the science teacher of class X as the sample determinant, design the learning activity by applying the chemondro media to the flipped class learning model and develop the learning tool (syllabus, RPP and LKS), make research instrument consisting of soa- a matter of multiple choice of electrolyte solution materials and conducting experimental research instruments outside the sample study class.

At the implementation stage of the research, implementing the learning in accordance with the RPP which has been prepared in the class that has been used as the sample of research that is class X IPA 1 (experimental group) and class X IPA 2 (control group) three meetings and ending in post test experimental class and control class to evaluate student learning outcomes at SMA Negeri 1 Karangmojo. And at SMAN N 2 Playen, implementing learning in accordance with RPP that has been prepared in the class that has been used as a research sample that is class X IPA 2 (experimental group) and class X IPA 3 (control group) three meetings and ending post- test in the experimental class and control class to evaluate student learning outcomes.

The data in this study include the validity of instructional devices, the implementation of learning tools and the test of learning ability. Data collection techniques include observation and multiple choice tests. Instruments used in the study consist of Learning Implementation Plan (RPP), student worksheet (LKS), Sheet implementation of learning and multiple choice test questions.

The learning implementation plan (RPP) is an instrument to provide treatment to the sample. RPP used by researchers in this research there are two types, namely RPP for experimental class using flippef class learning model + Media Chemondro and RPP for control class using 5M + Media Powerpoint learning model. The LKS Sheet is used to obtain information on the use of chemondro. Utilization of chemondro is a question designed on the LKS as one source of learning and teaching materials used.

Data were obtained from a written test at the end of the meeting. The form of multiple choice questions consists of 21 questions. This form of multiple choice questions aims to see the student's learning outcomes during the course of the research. The number of questions is based on the adjustment of learning time obtained. The research instrument is in the form of multiple choice questions, first tested outside the research sample that aims to determine the validity, reliability, degree of difficulty and distinguishing power. Testing of this instrument is done to know that the research instruments that have been prepared meet the requirements as 
a good instrument. Problems that can be used as a measuring tool is a matter of valid, reliable, and have a distinguishing power is enough, good, or very good. After that new validated questions were given to the students in the experimental and control class.

Instrument validity is done by using content validity and construct validity. Content validation is by examining the instrument grid to ensure that the instrument represents the entire content or material that should be mastered by the synthesis of theories about the concept of each variable to be measured, from the formulation of the construct, the determination of the indicator, to the elaboration and the writing of the items instrument items.

Instrument validity is done by using content validity and construct validity. Content validation is by examining the instrument grid to ensure that the instrument represents the entire content or material that should be mastered by the synthesis of theories about the concept of each variable to be measured, from the formulation of the construct, the determination of the indicator, to the elaboration and the writing of the items instrument items.

Normality test using Kolmogorov-Smirnov test with SPSS software. Homegeneity tests were also conducted to determine whether the variance between the tested groups was different or not, the variance was homogeneous or heterogeneous. The homogeneity of the data was tested with SPSS software using Levene test.

The analysis is done descriptively quantitative. The calculation is done by calculating the student score from the use of chemondro media which is integrated in the LKS for three meetings then averaged. After obtaining the average calculation of LKS score during the three meetings of students in the experimental class, then the data will then be included into the SPSS data as the dependent variable (X) and the learning result data (post-test) from the students in the experimental class as the independent variable (Y). The data is then analyzed by simple linear regression to find out how big influence the application of chemondro media on the model of learning flipped class to the ability of student learning outcomes. Analysis of the effect of chemondro media on the flipped class learning model on students' learning achievement was done by independent samples t test.

\section{RESEARCH RESULTS AND DISCUSSION}

The learning process ends with posttest. After applying chemondro media on flipped class model done posttest, which aims to determine the ability of student learning outcomes after following the learning process. Table 2 below shows descriptive results of posttest of students' learning achievement abilities.
TABLE 2. The result of descriptive analysis of students' learning ability.

\begin{tabular}{|c|c|c|}
\hline \multirow{3}{*}{$\begin{array}{c}\text { Descriptive } \\
\text { Statistics Results }\end{array}$} & \multirow{2}{*}{$\begin{array}{c}\text { Experiment Class } \\
\text { Flipped Class }\end{array}$} & \multirow{2}{*}{$\frac{\text { Control Class }}{5 \mathrm{M}}$} \\
\hline & & \\
\hline & Posttest & Posttest \\
\hline Average & 83,80 & 77,09 \\
\hline The highest score & 95 & 95 \\
\hline The lowest score & 6 & 61 \\
\hline SD & 9,54 & 10,96 \\
\hline
\end{tabular}

The result of the descriptive analysis of students' learning achievement shows that the students from the experimental class had an average of 83.80 after following the learning with the flipped class model. While in the control class average ability of student learning outcomes of 77,09 after following the learning process. Based on the data presented in the table can be concluded that the average ability of student learning outcomes in the class that applied chemondro media on the flipped class model higher than the class with $5 \mathrm{M}$ model. In table 3 , we present data normality postes ability of student learning outcomes.

TABLE 3. Normality Result Postes Ability Learning Outcomes

\begin{tabular}{|c|c|c|c|c|}
\hline Variables & Model & $\begin{array}{c}\text { Kolmogrov- } \\
\text { Smirnov Z }\end{array}$ & Sig. & Inf. \\
\hline \multirow{2}{*}{$\begin{array}{c}\text { Learning } \\
\text { Outcomes }\end{array}$} & $F C$ & 1,100 & 0,177 & $\mathrm{~N}$ \\
\cline { 2 - 5 } & $5 \mathrm{M}$ & 1,296 & 0,069 & $\mathrm{~N}$ \\
\hline
\end{tabular}

Based on the results of normality test with KolmogrovSmirnov on the result of postes ability of student learning outcomes, showed that postes result data is normal distributed, that is show significance value above 0,05 .

Table 4 below presents the results of homogeneity test of variance with Levene test on postes of student learning outcomes.

TABLE 4. Homogeneity Test Results of Variance with Levene Test.

\begin{tabular}{|c|c|c|c|}
\hline & $\begin{array}{c}\text { Levene } \\
\text { Statistic }\end{array}$ & Sig. & Inf. \\
\hline $\begin{array}{c}\text { Posttest } \\
\text { Learning } \\
\text { Outcomes }\end{array}$ & 2,925 & 0,090 & Homogen \\
\hline
\end{tabular}

Based on the table of variance homogeneity test with Levene test showed that the value of posttes ability learning ability is 0.090 which shows the value above 0.05 which means the variance is homogeneous.

Table 5 below presents the results of homogeneity matrix of variance in multivariate analysis of variance (manova) test with Box's $M$ test on posttest of student learning outcomes. 
TABLE 5. Homogeneity Test Results of Variance with Levene Test.

\begin{tabular}{|c|c|c|c|}
\hline Box's M & $\boldsymbol{F}$ & Sig. & Inf. \\
\hline 2,211 & 0,721 & 0,539 & Homogen \\
\hline
\end{tabular}

Based on the table of matrix variance homogeneity test with Levene test showed that the value of posttes ability learning ability is 0.090 which shows the value above 0.05 which means the variance is homogeneous.

In the next stage hypothesis testing is done with Test of Betwen-Subject on manova test The test results can be seen in table 6 .

TABLE 6. Test of Between-subjects

\begin{tabular}{|c|c|c|}
\hline Variable & Sig. & $\begin{array}{c}\text { Partial Eta } \\
\text { Squared }\end{array}$ \\
\hline $\begin{array}{l}\text { Learning } \\
\text { Outcome }\end{array}$ & 0,001 & 0,098 \\
\hline
\end{tabular}

Based on table 6 , it is known the significance value (2tailed) is 0.001 . Sig. $(0,001)<\alpha(0,025)$ then $\mathrm{H}_{0}$ is rejected. This means that in the experimental class there is a significant influence of the use of chemondro media on the flipped class model on the ability of student learning outcomes than control class.

Flipped class learning model is one of the instructional models suggested in the 2013 curriculum because this model is a learning model that gives students the opportunity to repeat home learning so as to stimulate learners to learn. By applying this flipped class learning model students are required to practice how to understand the material during home study.

The influence of the use of chemondro media on the flipped class model can be seen in the results of descriptive data and hypothesis test results. Descriptive data shows the average score of the experiment class is higher than the control class. Likewise with Test of Between-subjects in Manova test results concluded that the use of chemondro media on the flipped class model has a significant effect on the ability of student learning outcomes with influence amount $9,8 \%$.

The positive influence of the use of chemondro media on the flipped class model on the ability of student learning outcomes can be explained because of the influence of the use of chemondro media and flipped class model. Chemondro Media is an interactive learning media on android users which includes the concept of chemical theory, in game questions and virtual lab simulations.

According learning outcomes is the acquisition of learning process in accordance with the purpose of learning [12]. Acquisition includes cognitive domain, knowledge, or insight; affective sphere or attitude and appreciation; as well as psychomotor, skill or behavioral areas. The cognitive domain is primarily the result it gets while the affective and psychomotor spheres are derived as a result of the learning process, both instructional effects and unplanned side effects in teaching [14]. Thus it can be concluded that the learning outcome is the ability obtained from penglaman learning students. As well as research conducted showed good learning achievements with the help of learning media on mobile learning (android) [4] [8] [15].

The Flipped classrom model of learning, this model applies traditional learning that should be in class but applied at home. And if the traditional learning is done at home then complete the homework in the classroom during the lesson. Reversing the learning in flipped classroom can be adapted to the style, method and circumstances. Each teacher can use their version in applying flipped classroom [2]. In this case, researchers apply the chemondro media as a learning resource and whatssup application as a place to discuss online and deliver material. The results of the study on the effects of the Flipped Classroom show students better academic performance than the classical classes [13]. Another study to the impact of flipped classroom proves that with this model provides more learning outcomes than classical learning. The study also showed that flipped classroom provides benefits to underachieving students rather than high achievers and average students [3].

\section{CONCLUSION}

Based on the results of data analysis and discussion, it can be concluded that the use of chemondro media on the flipped class model influences the ability of student learning outcomes in learning chemistry of electrolyte solution in SMAN.

The ability of current learning outcomes greatly needs to be developed and enhanced for students as a conceptual understanding, and that takes time. For the next researcher I suggest that the research time can be done over a longer period of time and with a wider population and sample than the current researcher does.

To support the implementation of the 2013 curriculum and meet the standards of graduates listed in it, teachers are expected to apply the use of chemondro media on this flipped class learning model in learning, especially in Chemistry learning in high school so that the ability of student learning outcomes can be developed properly.

\section{REFERENCES}

[1] Bergmann. J and Sams. A, Flip your classroom: Reach every student in every class every day, Virginia: ASCD, 2012 pp.15

[2] Bergmann. J and Sams. A, Flip Learning: Gateaway to student engagement, Oregon-Washington DC: Eugene, 2014, pp.3

[3] Bhagat. K. K, Chang C. N and Chang C. Y. The impact of the flipped classroom on mathematics concept learning in high school, Educational Technology \& Society, 2016, vol.19, pp.140

[4] Hwang. G. J, Wu. .P H, Zhuang. Y. Y, and Huang. Y. M, Effects of the inquiry-based mobile learning model on the cognitive load and learning achievment of students, Interactive Learning Environments, 2013, vol.21, pp.358 
[5] Motta. M, A blended learning environment based on the principles of deliberate practice for the acquistion of interpreting skills, The Interpreter and Translator Trainer, 2016, vol.10, pp.138

[6] Organisation for Economic Co-operation and Development, PISA: Results in focus, Paris: OECD Publishing, 2015, pp.5

[7] Ozden. M, The effect of content knowledge on pedagogical content knowledge: the case of teaching phases of matters, Educational Sciences: Theory and Practice, 2008, vol.8, pp.637-638

[8] Perez. M. V. L, Lopez. M. C. P, and Ariza. L. R, Blended learning in higher education: Students' perceptions and their relation to outcomes, Computers \& Education, 2011, vol.56. pp.822

[9] Pranowo. H. D, Teknologi informasi dalam mendukung riset di bidang kimia, Prosiding Seminar Nasional Kimia dan Pendidikan Kimia, 2009 vol.10

[10] Presiden, R. I, Peraturan Pemerintah Republik Indonesia Nomor 17, Tahun 2010, tentang Pengelolaan dan Penyelenggaran Pendidikan Jakarta: Indonesia, 2010, pp.96
[11] Presidenm R. I. Peraturan Menteri Pendidikan dan Kebudayaan Nomor 54, Tahun 2013, tentang Standar Kompetensi Lulusan Pendidikan Dasar dan Menengah, Jakarta: Indonesia, 2013, pp.3

[12] Puwanto, Evaluasi Hasil Belajar. 2016, Yogyakarta: Pustaka Pelajar, pp. 45

[13] Schultz. D, Duffield. S, Rasmussen, S. C, and Wageman. J, Effect of the flipped classroom model on student performance for advanced placemanet high school chemistry education, Journal of Chemical Education, 2014, vol.9, pp.1338

[14] Sudjana. N, Penilaian Hasil Proses Belajar Mengajar, Bandung: Remaja Rosdakarya, 2016, pp.57

[15] Trifanto. F, Developing android-based learning media for chemistry on electrolyte solution increase self directed learning and students learning achievment in SMA/MA, Yogyakarta: Universitas Negeri Yogyakarta, 2015, pp. 83, 84 